\title{
Statistical Analysis on the Static Characteristics of the Geosynthetic Encased Stone Column
}

\author{
Fang Ou Yang ( $\square$ ouyangfang26@126.com ) \\ Hubei University of Education \\ Yingang Wang \\ Hubei University of Education \\ Zuoju Wu \\ Southwest University of Science and Technology \\ Zhijia Wang \\ Hainan University
}

\section{Research Article}

Keywords: Geosynthetic encased stone column, stone column, composite ground, static load

Posted Date: December 8th, 2021

DOI: https://doi.org/10.21203/rs.3.rs-1137093/v1

License: () (1) This work is licensed under a Creative Commons Attribution 4.0 International License. Read Full License 


\section{Abstract}

The geosynthetic encased stone column is made of stone column encased with geosynthetic encasement. The geosynthetic encased stone column is often used for foundation treatment of roadbeds, dams, buildings and other structures. At present, a series of new developments have been made in the researches of bearing capacity, stress concentration ratio and deformation of the geosynthetic encased stone column. This paper statistically analyzes the three important static characteristics of the geosynthetic encased stone column.

\section{Introduction}

Geosynthetic encased stone column (ESC) is made by enfolding the stone column (SC) with a geosynthetic encasement. The ESC includes fully encased stone column and partially encased stone column, and the former one with encasement length equaling to the column length, and the latter one with encasement length less than the column length, as shown in Fig. 1. Geosynthetic or geotextile are often chosen to be the material of the encasement.

The encasement could constrain the column deformation, and prevent the gravel from leaking into the surrounding soil. The stiffness of ESC is higher than SC, which induces a larger stress concentration ratio. The smaller deformation and larger stiffness contribute to higher bearing capacity for the ESC.

Currently, the main and effective approach to study the static characteristics of ESCs is to use experiments, including laboratory model tests or in-situ fullscale tests. Experiments in the references from 2007 to 2021 were collected. In the paper, the bearing capacity, stress concentration ratio, and pile deformation of ESCs in these experiments were analyzed.

\section{Static Characteristics}

\section{Bearing capacity}

Allowable bearing capacity and ultimate bearing capacity of the geosynthetic encased stone columns (ESCs) are collected from different model tests and listed in Table 1. The allowable bearing capacity is obtained at the pressure of elastic state tending to plastic state of ground. The ultimate bearing capacity is obtained at the pressure in a failure state of the ground. Table 1 shows that the allowable bearing capacity ratios of the ESCs to unreinforced ground are between 2.5 and 15.11. The ultimate bearing capacity ratios of the ESCs to unreinforced ground are between 1.1 and 34.6 . The large allowable bearing capacity ratio and large ultimate bearing capacity ratio both occur in the condition of small shear strength of soil. The allowable bearing capacity of ESCs is 1.5 to 8.5 times that of the stone columns (SCs), and the ultimate bearing capacity of the ESCs is 1.0 to 9.4 times that of the SCs under different conditions for different experiments. 
Table 1

Bearing capacity of soil reinforced by geosynthetic encased stone columns (ESCs)

\begin{tabular}{|c|c|c|c|c|c|c|c|c|}
\hline $\begin{array}{l}\text { Case } \\
\text { No. }\end{array}$ & $\begin{array}{l}\text { Undrained } \\
\text { shear } \\
\text { strength } \\
\text { of soil / } \\
\mathrm{kPa}\end{array}$ & $\begin{array}{l}\text { Tensile load of } \\
\text { encasement at } \\
\text { strain } \varepsilon=5 \% \\
/\left(\mathrm{kN} \cdot \mathrm{m}^{-1}\right)\end{array}$ & $\begin{array}{l}\text { Allowable bearing } \\
\text { capacity ratio of } \\
\text { SCs to } \\
\text { unreinforced } \\
\text { ground }\end{array}$ & $\begin{array}{l}\text { Allowable bearing } \\
\text { capacity ratio of } \\
\text { ESCs to } \\
\text { unreinforced } \\
\text { ground }\end{array}$ & $\begin{array}{l}\text { Limited bearing } \\
\text { capacity ratio of } \\
\text { SCs to } \\
\text { unreinforced } \\
\text { ground }\end{array}$ & $\begin{array}{l}\text { Limited bearing } \\
\text { capacity ratio of } \\
\text { ESCs to } \\
\text { unreinforced } \\
\text { ground }\end{array}$ & References & $\begin{array}{l}\text { Additional } \\
\text { information }\end{array}$ \\
\hline 1 & 15 & 1 & 1.86 & 2.86 & 1.3 & 1.5 & $\begin{array}{l}\text { Mehrannia } \\
\text { et al., } 2018\end{array}$ & $\begin{array}{l}l=350 \mathrm{~mm} \\
d=60 \mathrm{~mm}\end{array}$ \\
\hline 2 & 10 & 8.75 & 1.5 & 3.33 & 1.8 & 3.6 & $\begin{array}{l}\text { Debnath } \\
\text { and Dey, } \\
2017\end{array}$ & $\begin{array}{l}l=300 \mathrm{~mm} \\
d=50 \mathrm{~mm} \\
s=2.5 d\end{array}$ \\
\hline 3 & 10 & 8.75 & 1.5 & 4 & 2.3 & 2.5 & $\begin{array}{l}\text { Debnath } \\
\text { and Dey, } \\
2017\end{array}$ & $\begin{array}{l}I=300 \mathrm{~mm}, \\
d=50 \mathrm{~mm}, \\
s=2.5 \mathrm{~d}, \mathrm{mat} \\
\text { thickness of } \\
20 \mathrm{~mm}\end{array}$ \\
\hline 4 & 10 & 8.75 & 1.5 & 4.87 & 1.8 & 4.5 & $\begin{array}{l}\text { Debnath } \\
\text { and Dey, } \\
2017\end{array}$ & $\begin{array}{l}I=300 \mathrm{~mm}, \\
d=50 \mathrm{~mm}, \\
s=2.5 \mathrm{~d}, \text { mat } \\
\text { thickness of } \\
30 \mathrm{~mm}\end{array}$ \\
\hline 5 & 10 & 8.75 & 1.5 & 5.33 & 3.3 & 3.5 & $\begin{array}{l}\text { Debnath } \\
\text { and Dey, } \\
2017\end{array}$ & $\begin{array}{l}I=300 \mathrm{~mm}, \\
d=50 \mathrm{~mm}, \\
s=2.5 \mathrm{~d}, \text { mat } \\
\text { thickness of } \\
40 \mathrm{~mm}\end{array}$ \\
\hline 6 & 10 & 8.75 & 1.5 & 5.77 & 1.8 & 5 & $\begin{array}{l}\text { Debnath } \\
\text { and Dey, } \\
2017\end{array}$ & $\begin{array}{l}I=300 \mathrm{~mm}, \\
d=50 \mathrm{~mm}, \\
s=2.5 d, \text { mat } \\
\text { thickness of } \\
60 \mathrm{~mm}\end{array}$ \\
\hline 7 & 10 & 8.75 & 1.5 & 6.1 & 4.3 & 4.5 & $\begin{array}{l}\text { Debnath } \\
\text { and Dey, } \\
2017\end{array}$ & $\begin{array}{l}I=300 \mathrm{~mm}, \\
d=50 \mathrm{~mm}, \\
S=2.5 \mathrm{~d}, \mathrm{mat} \\
\text { thickness of } \\
80 \mathrm{~mm}\end{array}$ \\
\hline 8 & 10 & 8.75 & 1.5 & 7.67 & 4.3 & 10.5 & $\begin{array}{l}\text { Debnath } \\
\text { and Dey, } \\
2017\end{array}$ & $\begin{array}{l}I=300 \mathrm{~mm}, \\
d=50 \mathrm{~mm}, \\
s=2.5 d, \text { mat } \\
\text { thickness of } \\
30 \mathrm{~mm}\end{array}$ \\
\hline 9 & 12 & 24 & - & - & 4.1 & 5.7 & $\begin{array}{l}\text { Demir and } \\
\text { Sarici, } \\
2017\end{array}$ & - \\
\hline 10 & 3.4 & 4.75 & 1.5 & 7 & 5.3 & 9.6 & $\begin{array}{l}\text { Ou Yang et } \\
\text { al., 2016a }\end{array}$ & $\begin{array}{l}d=10 \mathrm{~cm}, I \\
=65 \mathrm{~cm}\end{array}$ \\
\hline 11 & 3.4 & 10 & 1.5 & 2.5 & 2.3 & 3.1 & $\begin{array}{l}\text { Ou Yang et } \\
\text { al., 2016a }\end{array}$ & $\begin{array}{l}d=10 \mathrm{~cm}, l \\
=65 \mathrm{~cm}, \\
l_{\mathrm{esc}}=4 d\end{array}$ \\
\hline 12 & 3.4 & 10 & 1.5 & 11 & 2.3 & 13.5 & $\begin{array}{l}\text { Ou Yang et } \\
\text { al., 2016a }\end{array}$ & $\begin{array}{l}d=10 \mathrm{~cm}, I \\
=65 \mathrm{~cm}\end{array}$ \\
\hline 13 & 10 & 0.39 & - & - & 1.2 & 1.3 & $\begin{array}{l}\text { Fattah et } \\
\text { al., } 2016\end{array}$ & $\begin{array}{l}d=70 \mathrm{~mm}, \\
H_{d}=200 \mathrm{~mm}, \\
/ / d=5, \\
\text { floating pile, } \\
s=2.5 d\end{array}$ \\
\hline 14 & 10 & 0.39 & - & - & 1.1 & 1.2 & $\begin{array}{l}\text { Fattah et } \\
\text { al., } 2016\end{array}$ & $\begin{array}{l}d=70 \mathrm{~mm}, \\
H_{d}=200 \mathrm{~mm}, \\
/ / d=5, \\
\text { floating pile, } \\
s=3 d\end{array}$ \\
\hline 15 & 10 & 0.39 & - & - & 1 & 1.1 & $\begin{array}{l}\text { Fattah et } \\
\text { al., } 2016\end{array}$ & $\begin{array}{l}d=70 \mathrm{~mm}, \\
H_{d}=200 \mathrm{~mm}, \\
/ / d=5, \\
\text { floating pile, } \\
s=4 d\end{array}$ \\
\hline
\end{tabular}




\begin{tabular}{|c|c|c|c|c|c|c|c|c|}
\hline $\begin{array}{l}\text { Case } \\
\text { No. }\end{array}$ & $\begin{array}{l}\text { Undrained } \\
\text { shear } \\
\text { strength } \\
\text { of soil / } \\
\mathrm{kPa}\end{array}$ & $\begin{array}{l}\text { Tensile load of } \\
\text { encasement at } \\
\text { strain } \varepsilon=5 \% \\
/\left(\mathrm{kN} \cdot \mathrm{m}^{-1}\right)\end{array}$ & $\begin{array}{l}\text { Allowable bearing } \\
\text { capacity ratio of } \\
\text { SCs to } \\
\text { unreinforced } \\
\text { ground }\end{array}$ & $\begin{array}{l}\text { Allowable bearing } \\
\text { capacity ratio of } \\
\text { ESCs to } \\
\text { unreinforced } \\
\text { ground }\end{array}$ & $\begin{array}{l}\text { Limited bearing } \\
\text { capacity ratio of } \\
\text { SCs to } \\
\text { unreinforced } \\
\text { ground }\end{array}$ & $\begin{array}{l}\text { Limited bearing } \\
\text { capacity ratio of } \\
\text { ESCs to } \\
\text { unreinforced } \\
\text { ground }\end{array}$ & References & $\begin{array}{l}\text { Additional } \\
\text { information }\end{array}$ \\
\hline 16 & 10 & 0.39 & - & - & 1.2 & 1.4 & $\begin{array}{l}\text { Fattah et } \\
\text { al., } 2016\end{array}$ & $\begin{array}{l}d=70 \mathrm{~mm}, \\
H_{d}=200 \mathrm{~mm}, \\
/ / d=8, \text { end } \\
\text { bearing pile, } \\
s=2.5 d\end{array}$ \\
\hline 17 & 10 & 0.39 & - & - & 1.1 & 1.2 & $\begin{array}{l}\text { Fattah et } \\
\text { al., } 2016\end{array}$ & $\begin{array}{l}d=70 \mathrm{~mm}, \\
H_{d}=200 \mathrm{~mm}, \\
/ / \mathrm{d}=8, \text { end } \\
\text { bearing pile, } \\
s=3 d\end{array}$ \\
\hline 18 & 10 & 0.39 & - & - & 1.1 & 1.2 & $\begin{array}{l}\text { Fattah et } \\
\text { al., } 2016\end{array}$ & $\begin{array}{l}d=70 \mathrm{~mm}, \\
H_{d}=200 \mathrm{~mm}, \\
/ / d=8, \text { end } \\
\text { bearing pile, } \\
s=4 d\end{array}$ \\
\hline 19 & 10 & 0.39 & - & - & 1.3 & 1.4 & $\begin{array}{l}\text { Fattah et } \\
\text { al., } 2016\end{array}$ & $\begin{array}{l}d=70 \mathrm{~mm}, \\
H_{d}=250 \mathrm{~mm}, \\
/ / d=5, \\
\text { floating pile, } \\
s=2.5 d\end{array}$ \\
\hline 20 & 10 & 0.39 & - & - & 1.3 & 1.3 & $\begin{array}{l}\text { Fattah et } \\
\text { al., } 2016\end{array}$ & $\begin{array}{l}d=70 \mathrm{~mm}, \\
H_{d}=250 \mathrm{~mm}, \\
l / d=5, \\
\text { floating pile, } \\
s=3 d\end{array}$ \\
\hline 21 & 10 & 0.39 & - & - & 1.2 & 1.2 & $\begin{array}{l}\text { Fattah et } \\
\text { al., } 2016\end{array}$ & $\begin{array}{l}d=70 \mathrm{~mm}, \\
H_{d}=250 \mathrm{~mm}, \\
/ / d=5, \\
\text { floating pile, } \\
s=4 d\end{array}$ \\
\hline 22 & 10 & 0.39 & - & - & 1.4 & 1.6 & $\begin{array}{l}\text { Fattah et } \\
\text { al., } 2016\end{array}$ & $\begin{array}{l}d=70 \mathrm{~mm}, \\
H_{d}=250 \mathrm{~mm}, \\
/ / d=8, \text { end } \\
\text { bearing pile, } \\
s=2.5 d\end{array}$ \\
\hline 23 & 10 & 0.39 & - & - & 1.3 & 1.5 & $\begin{array}{l}\text { Fattah et } \\
\text { al., } 2016\end{array}$ & $\begin{array}{l}d=70 \mathrm{~mm}, \\
H_{d}=250 \mathrm{~mm}, \\
/ / d=8, \text { end } \\
\text { bearing pile, } \\
s=3 d\end{array}$ \\
\hline 24 & 10 & 0.39 & - & - & 1.2 & 1.3 & $\begin{array}{l}\text { Fattah et } \\
\text { al., } 2016\end{array}$ & $\begin{array}{l}d=70 \mathrm{~mm}, H_{d} \\
=250 \mathrm{~mm}, I \\
/ d=8, \text { end } \\
\text { bearing pile, } \\
s=4 d\end{array}$ \\
\hline 25 & 10 & 0.39 & - & - & 1.5 & 1.6 & $\begin{array}{l}\text { Fattah et } \\
\text { al., } 2016\end{array}$ & $\begin{array}{l}d=70 \mathrm{~mm}, \\
H_{d}=300 \mathrm{~mm}, \\
/ / d=5, \\
\text { floating pile, } \\
s=2.5 d\end{array}$ \\
\hline 26 & 10 & 0.39 & - & - & 1.4 & 1.6 & $\begin{array}{l}\text { Fattah et } \\
\text { al., } 2016\end{array}$ & $\begin{array}{l}d=70 \mathrm{~mm}, \\
H_{d}=300 \mathrm{~mm}, \\
l / d=5, \\
\text { floating pile, } \\
s=3 d\end{array}$ \\
\hline 27 & 10 & 0.39 & - & - & 1.3 & 1.4 & $\begin{array}{l}\text { Fattah et } \\
\text { al., } 2016\end{array}$ & $\begin{array}{l}d=70 \mathrm{~mm}, \\
H_{d}=300 \mathrm{~mm}, \\
l / d=5, \\
\text { floating pile, } \\
s=4 d\end{array}$ \\
\hline 28 & 10 & 0.39 & - & - & 1.7 & 1.8 & $\begin{array}{l}\text { Fattah et } \\
\text { al., } 2016\end{array}$ & $\begin{array}{l}d=70 \mathrm{~mm}, H_{d} \\
=300 \mathrm{~mm}, I \\
/ d=8, \text { end } \\
\text { bearing pile, } \\
s=2.5 d\end{array}$ \\
\hline
\end{tabular}




\begin{tabular}{|c|c|c|c|c|c|c|c|c|}
\hline $\begin{array}{l}\text { Case } \\
\text { No. }\end{array}$ & $\begin{array}{l}\text { Undrained } \\
\text { shear } \\
\text { strength } \\
\text { of soil / } \\
\mathrm{kPa}\end{array}$ & $\begin{array}{l}\text { Tensile load of } \\
\text { encasement at } \\
\text { strain } \varepsilon=5 \% \\
/\left(\mathrm{kN} \cdot \mathrm{m}^{-1}\right)\end{array}$ & $\begin{array}{l}\text { Allowable bearing } \\
\text { capacity ratio of } \\
\text { SCs to } \\
\text { unreinforced } \\
\text { ground }\end{array}$ & $\begin{array}{l}\text { Allowable bearing } \\
\text { capacity ratio of } \\
\text { ESCs to } \\
\text { unreinforced } \\
\text { ground }\end{array}$ & $\begin{array}{l}\text { Limited bearing } \\
\text { capacity ratio of } \\
\text { SCs to } \\
\text { unreinforced } \\
\text { ground }\end{array}$ & $\begin{array}{l}\text { Limited bearing } \\
\text { capacity ratio of } \\
\text { ESCs to } \\
\text { unreinforced } \\
\text { ground }\end{array}$ & References & $\begin{array}{l}\text { Additional } \\
\text { information }\end{array}$ \\
\hline 29 & 10 & 0.39 & - & - & 1.5 & 1.7 & $\begin{array}{l}\text { Fattah et } \\
\text { al., } 2016\end{array}$ & $\begin{array}{l}d=70 \mathrm{~mm}, H_{d} \\
=300 \mathrm{~mm}, / \\
/ d=8, \text { end } \\
\text { bearing pile, } \\
s=3 d\end{array}$ \\
\hline 30 & 10 & 0.39 & - & - & 1.4 & 1.6 & $\begin{array}{l}\text { Fattah et } \\
\text { al., } 2016\end{array}$ & $\begin{array}{l}d=70 \mathrm{~mm}, H_{d} \\
=300 \mathrm{~mm}, I \\
/ d=8, \text { end } \\
\text { bearing pile, } \\
s=4 d\end{array}$ \\
\hline 31 & 3.4 & 20 & - & - & 1.1 & 1.7 & $\begin{array}{l}\text { Gu et al., } \\
2015\end{array}$ & $\begin{array}{l}d=200 \mathrm{~mm}, \\
l_{\text {esc }}=2 d \\
\text { composite } \\
\text { ground }\end{array}$ \\
\hline 32 & 3.4 & 20 & - & - & 3.8 & 6 & $\begin{array}{l}\text { Zhao et al., } \\
2014\end{array}$ & $\begin{array}{l}d=200 \mathrm{~mm} \\
l_{\mathrm{esc}}=2 d\end{array}$ \\
\hline 33 & 2.5 & 0.3 & 1.78 & 15.11 & 2 & 18.8 & $\begin{array}{l}\text { Murugesan } \\
\text { and } \\
\text { Rajagopal, } \\
2010\end{array}$ & $\begin{array}{l}d=50 \mathrm{~mm}, \\
l=600 \mathrm{~mm}\end{array}$ \\
\hline 34 & 2.5 & 0.3 & 2.22 & 9.11 & 2.5 & 12.4 & $\begin{array}{l}\text { Murugesan } \\
\text { and } \\
\text { Rajagopal, } \\
2010\end{array}$ & $\begin{array}{l}d=75 \mathrm{~mm}, \\
l=600 \mathrm{~mm}\end{array}$ \\
\hline 35 & 2.5 & 0.3 & 2.44 & 7.11 & 3 & 9 & $\begin{array}{l}\text { Murugesan } \\
\text { and } \\
\text { Rajagopal, } \\
2010\end{array}$ & $\begin{array}{l}d=100 \mathrm{~mm}, \\
l=600 \mathrm{~mm}\end{array}$ \\
\hline 36 & 2.5 & 0.75 & 1.78 & 12.67 & 2 & 18.8 & $\begin{array}{l}\text { Murugesan } \\
\text { and } \\
\text { Rajagopal, } \\
2010\end{array}$ & $\begin{array}{l}d=50 \mathrm{~mm}, \\
l=600 \mathrm{~mm}\end{array}$ \\
\hline 37 & 2.5 & 0.75 & 2.22 & 9.11 & 2.5 & 13.4 & $\begin{array}{l}\text { Murugesan } \\
\text { and } \\
\text { Rajagopal, } \\
2010\end{array}$ & $\begin{array}{l}d=75 \mathrm{~mm}, \\
l=600 \mathrm{~mm}\end{array}$ \\
\hline 38 & 2.5 & 0.75 & 2.44 & 6 & 3 & 11 & $\begin{array}{l}\text { Murugesan } \\
\text { and } \\
\text { Rajagopal, } \\
2010\end{array}$ & $\begin{array}{l}d=100 \mathrm{~mm}, \\
l=600 \mathrm{~mm}\end{array}$ \\
\hline 39 & 2.5 & 0.1 & 2.22 & 5.91 & 2.5 & 7.6 & $\begin{array}{l}\text { Murugesan } \\
\text { and } \\
\text { Rajagopal, } \\
2010\end{array}$ & $\begin{array}{l}d=75 \mathrm{~mm}, \\
l=600 \mathrm{~mm}\end{array}$ \\
\hline 40 & 2.5 & 0.2 & 2.22 & 7.11 & 2.5 & 9.2 & $\begin{array}{l}\text { Murugesan } \\
\text { and } \\
\text { Rajagopal, } \\
2010\end{array}$ & $\begin{array}{l}d=75 \mathrm{~mm}, \\
l=600 \mathrm{~mm}\end{array}$ \\
\hline 41 & 2.5 & 0.3 & 2.22 & 9.11 & 2.5 & 12.4 & $\begin{array}{l}\text { Murugesan } \\
\text { and } \\
\text { Rajagopal, } \\
2010\end{array}$ & $\begin{array}{l}d=75 \mathrm{~mm}, \\
l=600 \mathrm{~mm}\end{array}$ \\
\hline 42 & 2.5 & 0.75 & 2.22 & 9.11 & 2.5 & 13.4 & $\begin{array}{l}\text { Murugesan } \\
\text { and } \\
\text { Rajagopal, } \\
2010\end{array}$ & $\begin{array}{l}d=75 \mathrm{~mm}, \\
l=600 \mathrm{~mm}\end{array}$ \\
\hline 43 & 5 & $\begin{array}{l}4.8 \text { (at 2\% } \\
\text { strain) }\end{array}$ & - & - & 1.6 & 4.7 & $\begin{array}{l}\text { Gniel and } \\
\text { Bouazza, } \\
2010\end{array}$ & $\begin{array}{l}l_{\mathrm{esc}}=75 \% / \\
d=51 \mathrm{~mm}\end{array}$ \\
\hline 44 & 2.5 & 0.77 & - & - & 5.7 & 34.6 & $\begin{array}{l}\text { Murugesan } \\
\text { and } \\
\text { Rajagopal, } \\
2007\end{array}$ & $\begin{array}{l}d=75 \mathrm{~mm}, / \\
=500 \mathrm{~mm}, \\
\text { end bearing } \\
\text { pile }\end{array}$ \\
\hline
\end{tabular}




\begin{tabular}{|c|c|c|c|c|c|c|c|c|}
\hline $\begin{array}{l}\text { Case } \\
\text { No. }\end{array}$ & $\begin{array}{l}\text { Undrained } \\
\text { shear } \\
\text { strength } \\
\text { of soil / } \\
\mathrm{kPa}\end{array}$ & $\begin{array}{l}\text { Tensile load of } \\
\text { encasement at } \\
\text { strain } \varepsilon=5 \% \\
/\left(\mathrm{kN} \cdot \mathrm{m}^{-1}\right)\end{array}$ & $\begin{array}{l}\text { Allowable bearing } \\
\text { capacity ratio of } \\
\text { SCs to } \\
\text { unreinforced } \\
\text { ground }\end{array}$ & $\begin{array}{l}\text { Allowable bearing } \\
\text { capacity ratio of } \\
\text { ESCs to } \\
\text { unreinforced } \\
\text { ground }\end{array}$ & $\begin{array}{l}\text { Limited bearing } \\
\text { capacity ratio of } \\
\text { SCs to } \\
\text { unreinforced } \\
\text { ground }\end{array}$ & $\begin{array}{l}\text { Limited bearing } \\
\text { capacity ratio of } \\
\text { ESCs to } \\
\text { unreinforced } \\
\text { ground }\end{array}$ & References & $\begin{array}{l}\text { Additional } \\
\text { information }\end{array}$ \\
\hline 45 & 2.5 & 0.57 & - & - & 5.7 & 25.1 & $\begin{array}{l}\text { Murugesan } \\
\text { and } \\
\text { Rajagopal, } \\
2007\end{array}$ & $\begin{array}{l}d=75 \mathrm{~mm}, l \\
=500 \mathrm{~mm}, \\
\text { end bearing } \\
\text { pile }\end{array}$ \\
\hline 46 & 2.5 & 0.18 & - & - & 5.7 & 21.4 & $\begin{array}{l}\text { Murugesan } \\
\text { and } \\
\text { Rajagopal, } \\
2007\end{array}$ & $\begin{array}{l}d=75 \mathrm{~mm}, / \\
=500 \mathrm{~mm}, \\
\text { end bearing } \\
\text { pile }\end{array}$ \\
\hline 47 & 2.5 & 0.09 & - & - & 5.7 & 18 & $\begin{array}{l}\text { Murugesan } \\
\text { and } \\
\text { Rajagopal, } \\
2007\end{array}$ & $\begin{array}{l}d=75 \mathrm{~mm}, / \\
=500 \mathrm{~mm}, \\
\text { end bearing } \\
\text { pile }\end{array}$ \\
\hline
\end{tabular}

The bearing capacity of the ESCs composite ground is mostly influenced by geosynthetic encasement modulus, encasement length, shear strength of soil, pile length to diameter ratio, area replacement ratio, and mat thickness (Debnath and Dey 2017; Fattah et al. 2016; Murugesan and Rajagopal 2010; Ou Yang et al. 2016b). When the shear strength of soil is low and modulus of geothesyntic encasement is large, the ESCs are much stronger than SCs. This is because that the SC gains large strength from surrounding soil, and the strength of the stone column significantly increases with the constraint of the stiffer geosynthetic encasement. Murugesan and Rajagopal (2010) found that the SC shows strain-softening behavior, while the ESC behaves similar to rigid pile during loading in model tests. The ESC behaves stiffer and the ESCs composite ground has larger bearing capacity compared to SCs. They also found that the reinforcement from the encasement decreases with an increase in pile diameter. Ou Yang et al. (2016) found that the strength of the ESC increases with the increase of the encasement length, and the fully encased stone column behaves best in model tests. The ESC with encasement length of three times diameter shows significant increase in bearing capacity compared to SC. Murugesan and Rajagopal (2007) found that the bearing capacity of ESCs increases with the increase of the area replacement ratio, and the ESCs composite ground behaves great at the pile to pile space of 2.5 times diameter. Debnath and Dey (2017) found that the optimal mat thickness is 0.15 to 0.2 times diameter of foundation, in which the composite ground shows the greatest bearing capacity.

Comparing the references of Murugesan and Rajagopal (2010) with Fattah et al. (2016), it can be found that the ESC shows more effective improvement over soil and SC in the lower soil strength case. Comparing the references of Debnath and Dey (2017) with Fattah et al. (2016), similar pile lengths, pile diameters, pile to pile spaces, and same shear strength of soil are in the two cases. The encasement modulus of the reference of Debnath and Dey (2017) is 22 times that of Fattah et al. (2016). The case of larger modulus of encasement (Debnath and Dey, 2017) has much higher limited bearing capacity of ESC reinforced ground compared to the smaller modulus of encasement case, although with different pile length to diameter ratios, pile to pile spaces, mat thicknesses and embankment loads, just as shown in Fig. 2. This indicates that the encasement modulus has important influence on the limit bearing capacity of ground. Fig. 2 also shows that the bearing capacity differences induced by mat thickness for the larger encasement modulus case are much larger than those induced by embankment load for the smaller encasement modulus case, which suggests that the large modulus may amplify the effects of the other parameters.

\section{Stress concentration ratio}

Stress concentration ratio is one of the important factors in the composite ground design, which shows the load shared by piles and soil. The stress concentration ratio $(n)$ is calculated by Equation 1. Mat didn't use in the model tests before 2015, and thus the stress concentration ratio wasn't considered in these references. The stress concentration ratio is studied in experiments with embankment load or mat in recent years. Stress concentration ratio of different geosynthetic encased stone columns (ESCs) composite grounds is shown in Table 2. As only a few experiments considered stress concentration ratio, some FEM results are also involved in Table 2 . The stress concentration ratio is obtained at a stable state or at an allowable load. From the table, it can be found that the stress concentration ratio is between 0.48 and 25 for the ESCs composite ground. The larger stress concentration ratio occurs at the smaller shear strength of the surrounding soil. The stress concentration ratio also increases with an increase in encasement modulus. The table also shows that the stress concentration ratio increases with the increase of the embankment load, and the stress concentration ratio is larger for the end bearing pile case compared to the floating pile case. 
Table 2

Stress concentration ratio of geosynthetic encased stone columns (ESCs)

\begin{tabular}{|c|c|c|c|c|c|c|}
\hline $\begin{array}{l}\text { Case } \\
\text { No. }\end{array}$ & $\begin{array}{l}\text { Undrained } \\
\text { shear } \\
\text { strength of } \\
\text { soil / } / \mathrm{kPa}\end{array}$ & $\begin{array}{l}\text { Tensile force of } \\
\text { Encasement at } \\
\text { strain } \varepsilon=5 \% \\
/\left(\mathrm{kN} \cdot \mathrm{m}^{-1}\right)\end{array}$ & $\begin{array}{l}\text { Stress } \\
\text { concentration } \\
\text { ratio of SC }\end{array}$ & $\begin{array}{l}\text { Stress } \\
\text { concentration } \\
\text { ratio of ESC }\end{array}$ & References & Additional information \\
\hline 1 & 5 & 6 & 2.5 & 5.65 & $\begin{array}{l}\text { Chen et al., } \\
2021\end{array}$ & $d=32 \mathrm{~mm}, I / d=12.5$, in a square pattern, $s=100 \mathrm{~mm}$ \\
\hline 2 & 5 & 1.05 & 2.5 & 4 & $\begin{array}{l}\text { Chen et al., } \\
2021\end{array}$ & $d=32 \mathrm{~mm}, l / d=12.5$, in a square pattern, $s=100 \mathrm{~mm}$ \\
\hline 3 & 5.6 & 6.6 & 1.9 & 7 & $\begin{array}{l}\text { Li et al., } \\
2021\end{array}$ & $\begin{array}{l}d=32 \mathrm{~mm}, / / d=12.5, \text { in a square pattern, } s=100 \mathrm{~mm} \text {, } \\
H_{d}=200 \mathrm{~mm} \text {, end bearing pile }\end{array}$ \\
\hline 4 & 5.6 & 0.9 & 1.9 & 4.9 & $\begin{array}{l}\text { Li et al., } \\
2021\end{array}$ & $\begin{array}{l}d=32 \mathrm{~mm}, I / d=12.5 \text {, in a square pattern, } s=100 \mathrm{~mm} \text {, } \\
H_{d}=200 \mathrm{~mm} \text {, end bearing pile }\end{array}$ \\
\hline 5 & 5.6 & 6.6 & 1.9 & 7.8 & $\begin{array}{l}\text { Li et al., } \\
2021\end{array}$ & $\begin{array}{l}d=32 \mathrm{~mm}, I / d=12.5 \text {, in a square pattern, } s=100 \mathrm{~mm} \text {, } \\
H_{d}=200 \mathrm{~mm} \text {, end bearing pile, with geogrids used as } \\
\text { horizontal reinforcement in the embankment }\end{array}$ \\
\hline 6 & 5.6 & 0.9 & 1.9 & 5.2 & $\begin{array}{l}\text { Li et al., } \\
2021\end{array}$ & $\begin{array}{l}d=32 \mathrm{~mm}, I / d=12.5 \text {, in a square pattern, } s=100 \mathrm{~mm} \text {, } \\
H_{d}=200 \mathrm{~mm} \text {, end bearing pile, with geogrids used as } \\
\text { horizontal reinforcement in the embankment }\end{array}$ \\
\hline 7 & 10 & 8.75 & 2 & 3.2 & $\begin{array}{l}\text { Debnath } \\
\text { and Dey, } \\
2017\end{array}$ & $l=300 \mathrm{~mm}, d=50 \mathrm{~mm}, s=2.5 d$ \\
\hline 8 & 10 & 8.75 & 2 & 3.2 & $\begin{array}{l}\text { Debnath } \\
\text { and Dey, } \\
2017\end{array}$ & $I=300 \mathrm{~mm}, d=50 \mathrm{~mm}, s=2.5 d$, mat thickness of $40 \mathrm{~mm}$ \\
\hline 9 & 10 & 8.75 & 2 & 4 & $\begin{array}{l}\text { Debnath } \\
\text { and Dey, } \\
2017\end{array}$ & $I=300 \mathrm{~mm}, d=50 \mathrm{~mm}, s=2.5 d$, mat thickness of $30 \mathrm{~mm}$ \\
\hline 10 & 12 & 31 & $3 \sim 6$ & $11 \sim 25$ & $\begin{array}{l}\text { Miranda et } \\
\text { al., } 2016\end{array}$ & - \\
\hline 11 & 10 & 0.39 & - & 0.94 & $\begin{array}{l}\text { Fattah et } \\
\text { al., } 2016\end{array}$ & $d=70 \mathrm{~mm}, / / d=5, s=2.5 d, H_{d}=200 \mathrm{~mm}$, floating pile \\
\hline 12 & 10 & 0.39 & - & 0.73 & $\begin{array}{l}\text { Fattah et } \\
\text { al., } 2016\end{array}$ & $d=70 \mathrm{~mm}, I / d=5, s=3 d, H_{d}=200 \mathrm{~mm}$, floating pile \\
\hline 13 & 10 & 0.39 & - & 0.48 & $\begin{array}{l}\text { Fattah et } \\
\text { al., } 2016\end{array}$ & $d=70 \mathrm{~mm}, / / d=5, s=4 d, H_{d}=200 \mathrm{~mm}$, floating pile \\
\hline 14 & 10 & 0.39 & - & 1.15 & $\begin{array}{l}\text { Fattah et } \\
\text { al., } 2016\end{array}$ & $d=70 \mathrm{~mm}, / / d=8, s=2.5 d, H_{d}=200 \mathrm{~mm}$, end bearing pile \\
\hline 15 & 10 & 0.39 & - & 0.9 & $\begin{array}{l}\text { Fattah et } \\
\text { al., } 2016\end{array}$ & $d=70 \mathrm{~mm}, I / d=8, s=3 d, H_{d}=200 \mathrm{~mm}$, end bearing pile \\
\hline 16 & 10 & 0.39 & - & 0.6 & $\begin{array}{l}\text { Fattah et } \\
\text { al., } 2016\end{array}$ & $d=70 \mathrm{~mm}, I / d=8, s=4 d, H_{d}=200 \mathrm{~mm}$, end bearing pile \\
\hline 17 & 10 & 0.39 & - & 1.47 & $\begin{array}{l}\text { Fattah et } \\
\text { al., } 2016\end{array}$ & $d=70 \mathrm{~mm}, / / d=5, s=2.5 d, H_{d}=250 \mathrm{~mm}$, floating pile \\
\hline 18 & 10 & 0.39 & - & 1.15 & $\begin{array}{l}\text { Fattah et } \\
\text { al., } 2016\end{array}$ & $d=70 \mathrm{~mm}, I / d=5, s=3 d, H_{d}=250 \mathrm{~mm}$, floating pile \\
\hline 19 & 10 & 0.39 & - & 0.65 & $\begin{array}{l}\text { Fattah et } \\
\text { al., } 2016\end{array}$ & $d=70 \mathrm{~mm}, I / d=5, s=4 d, H_{d}=250 \mathrm{~mm}$, floating pile \\
\hline 20 & 10 & 0.39 & - & 2.2 & $\begin{array}{l}\text { Fattah et } \\
\text { al., } 2016\end{array}$ & $d=70 \mathrm{~mm}, / / d=8, s=2.5 d, H_{d}=250 \mathrm{~mm}$, end bearing pile \\
\hline 21 & 10 & 0.39 & - & 1.4 & $\begin{array}{l}\text { Fattah et } \\
\text { al., } 2016\end{array}$ & $d=70 \mathrm{~mm}, / / d=8, s=3 d, H_{d}=250 \mathrm{~mm}$, end bearing pile \\
\hline 22 & 10 & 0.39 & - & 1 & $\begin{array}{l}\text { Fattah et } \\
\text { al., } 2016\end{array}$ & $d=70 \mathrm{~mm}, / / d=8, s=4 d, H_{d}=250 \mathrm{~mm}$, end bearing pile \\
\hline 23 & 10 & 0.39 & - & 2.1 & $\begin{array}{l}\text { Fattah et } \\
\text { al., } 2016\end{array}$ & $d=70 \mathrm{~mm}, I / d=5, s=2.5 d, H_{d}=300 \mathrm{~mm}$, floating pile \\
\hline 24 & 10 & 0.39 & - & 1.5 & $\begin{array}{l}\text { Fattah et } \\
\text { al., } 2016\end{array}$ & $d=70 \mathrm{~mm}, / / d=5, s=3 d, H_{d}=300 \mathrm{~mm}$, floating pile \\
\hline 25 & 10 & 0.39 & - & 0.9 & $\begin{array}{l}\text { Fattah et } \\
\text { al., } 2016\end{array}$ & $d=70 \mathrm{~mm}, / / d=5, s=4 d, H_{d}=300 \mathrm{~mm}$, floating pile \\
\hline
\end{tabular}




\begin{tabular}{|c|c|c|c|c|c|c|}
\hline $\begin{array}{l}\text { Case } \\
\text { No. }\end{array}$ & $\begin{array}{l}\text { Undrained } \\
\text { shear } \\
\text { strength of } \\
\text { soil } / \mathrm{kPa}\end{array}$ & $\begin{array}{l}\text { Tensile force of } \\
\text { Encasement at } \\
\text { strain } \varepsilon=5 \% \\
/\left(\mathrm{kN} \cdot \mathrm{m}^{-1}\right)\end{array}$ & $\begin{array}{l}\text { Stress } \\
\text { concentration } \\
\text { ratio of SC }\end{array}$ & $\begin{array}{l}\text { Stress } \\
\text { concentration } \\
\text { ratio of ESC }\end{array}$ & References & Additional information \\
\hline 26 & 10 & 0.39 & - & 3.6 & $\begin{array}{l}\text { Fattah et } \\
\text { al., } 2016\end{array}$ & $d=70 \mathrm{~mm}, / / d=8, s=2.5 d, H_{d}=300 \mathrm{~mm}$, end bearing pile \\
\hline 27 & 10 & 0.39 & - & 2 & $\begin{array}{l}\text { Fattah et } \\
\text { al., } 2016\end{array}$ & $d=70 \mathrm{~mm}, I / \mathrm{d}=8, s=3 d, H_{d}=300 \mathrm{~mm}$, end bearing pile \\
\hline 28 & 10 & 0.39 & - & 1.3 & $\begin{array}{l}\text { Fattah et } \\
\text { al., } 2016\end{array}$ & $d=70 \mathrm{~mm}, / / d=8, s=4 d, H_{d}=300 \mathrm{~mm}$, end bearing pile \\
\hline 29 & 3.4 & 20 & 9 & 13 & $\begin{array}{l}\text { Zhao et al., } \\
2014\end{array}$ & $d=200 \mathrm{~mm}, l_{\mathrm{esc}}=2 d$ \\
\hline 30 & $\begin{array}{l}15 \mathrm{kPa}(\mathrm{clay} \\
\text { layer at top) }\end{array}$ & 95 & - & 2.1 & $\begin{array}{l}\text { Almeida et } \\
\text { al., } 2014\end{array}$ & In-situ test, $l=11 \mathrm{~m}, d=80 \mathrm{~cm}, s=2 \mathrm{~m}$, in a square pattern \\
\hline 31 & 6.04 & 0.2 & 4.36 & 4.62 & $\begin{array}{l}\text { Duan, } \\
2012\end{array}$ & - \\
\hline 32 & 2.5 & 0.75 & 2 & 4.8 & $\begin{array}{l}\text { Murugesan } \\
\text { and } \\
\text { Rajagopal, } \\
2010\end{array}$ & $l=600 \mathrm{~mm}, d=50 \mathrm{~mm}$ \\
\hline 33 & 2.5 & 0.6 & 2 & 4.8 & $\begin{array}{l}\text { Murugesan } \\
\text { and } \\
\text { Rajagopal, } \\
2010\end{array}$ & $I=600 \mathrm{~mm}, d=50 \mathrm{~mm}$ \\
\hline 34 & 5 & 4.8 (strain of $2 \%$ ) & $2 \sim 3$ & $>10$ & $\begin{array}{l}\text { Gniel and } \\
\text { Bouazza, } \\
2010\end{array}$ & $d=51 \mathrm{~mm}, I_{\mathrm{esc}}=75 \% /$ \\
\hline 35 & 61 & - & - & 4.5 & $\begin{array}{l}\text { Lee et al., } \\
2008\end{array}$ & In-situ test, $d=0.8 \mathrm{~m}, l_{\mathrm{esc}}=3 d$ \\
\hline
\end{tabular}

Fattah et al. (2016) found that the stress concentration ratio increases with the increase of the area replacement ratio and the length-diameter ratio. Ou Yang et al. (2016a) found that the stress concentration ratio increases with the increase of the encasement modulus and encasement length.

$n=\sigma_{\mathrm{vc}} / \sigma_{\mathrm{vs}}(1)$

where, $\sigma_{\mathrm{vc}}=$ load shared by columns; $\sigma_{\mathrm{vs}}=$ load shared by soil.

\section{Radial deformation of piles}

Few tests have explored pile deformation due to the difficulty of measuring it in the experiment. Pile deformation data of model tests from references are collected and listed in Table 3. The radial strain of the column is calculated from Equation (2).

$$
\varepsilon=\frac{\Delta d}{d}
$$

2

Where, $d=$ pile diameter; $\Delta d=$ variation of pile diameter.

From Table 3, it can be found that the maximum deformation occurs at 1.5 to 4 times diameter depth for the fully encased stone column. As the modulus of the encasement increases, the depth of the maximum deformation downward. For the partially encased stone column, the maximum deformation just occurs under the encasement. 
Table 3

Radial strain of columns

\begin{tabular}{|c|c|c|c|c|c|c|c|c|c|c|}
\hline $\begin{array}{l}\text { Case } \\
\text { No. }\end{array}$ & $\begin{array}{l}\text { Undrained } \\
\text { shear } \\
\text { strength } \\
\text { of soil } \\
/ \mathrm{kPa}\end{array}$ & $\begin{array}{l}\text { Tensile } \\
\text { force at } 5 \% \\
\text { strain of } \\
\text { encasement } \\
(\mathrm{kN} / \mathrm{m})\end{array}$ & $\begin{array}{l}\text { The depth of } \\
\text { maximum } \\
\text { bulging } \\
\text { along the } \\
\text { pile /d }\end{array}$ & $\begin{array}{l}\text { Radial } \\
\text { strain at } \\
\text { SC } \\
\text { failure/(\%) }\end{array}$ & $\begin{array}{l}\text { Radial } \\
\text { strain at } \\
\text { ESC } \\
\text { failure/(\%) }\end{array}$ & $\begin{array}{l}\text { Encasement } \\
\text { tensile } \\
\text { strength } \\
/\left(\mathrm{kN} \cdot \mathrm{m}^{-1}\right)\end{array}$ & $\begin{array}{l}\text { Radial strain at } \\
\text { limit tensile load } \\
\text { for } \\
\text { encasement/(\%) }\end{array}$ & $\begin{array}{l}\text { Failure } \\
\text { mode of } \\
\text { ESCs }\end{array}$ & References & $\begin{array}{l}\text { Additior } \\
\text { informa }\end{array}$ \\
\hline 1 & 3.4 & 4.75 & $2 \sim 3$ & 14 & 7 & 11 & 22 & $\begin{array}{l}\text { Upper } \\
\text { punching }\end{array}$ & $\begin{array}{l}\text { Ou Yang et } \\
\text { al., 2016a }\end{array}$ & $\begin{array}{l}l=65 \mathrm{~cm}, \\
d=10 \mathrm{~cm}\end{array}$ \\
\hline 2 & 3.4 & 10 & $2 \sim 4$ & 14 & 4.4 & 43 & 25 & $\begin{array}{l}\text { Upper } \\
\text { punching }\end{array}$ & $\begin{array}{l}\text { Ou Yang et } \\
\text { al., 2016a }\end{array}$ & $\begin{array}{l}I=65 \mathrm{~cm} \\
d=10 \mathrm{~cm}\end{array}$ \\
\hline 3 & 3.4 & 10 & $\begin{array}{l}\text { 4 5 (under } \\
\text { encasement) }\end{array}$ & 14 & 4.4 & 43 & 25 & $\begin{array}{l}\text { Shear } \\
\text { failure } \\
\text { under } \\
\text { encasement }\end{array}$ & $\begin{array}{l}\text { Ou Yang et } \\
\text { al., 2016a }\end{array}$ & $\begin{array}{l}l=65 \mathrm{~cm} \\
d=10 \mathrm{~cm} \\
l_{\mathrm{esc}}=4 \mathrm{~d}\end{array}$ \\
\hline 4 & 10 & 8.75 & 2.84 & 14 & 8 & 12 & 24 & $\begin{array}{l}\text { Bulging } \\
\text { deformation } \\
\text { and } \\
\text { bending } \\
\text { deformation }\end{array}$ & $\begin{array}{l}\text { Debnath } \\
\text { and Dey, } \\
2017\end{array}$ & $\begin{array}{l}I=30 \mathrm{~cm} \\
d=5 \mathrm{~cm}, \\
s=2.5 d\end{array}$ \\
\hline 5 & 10 & 8.75 & 3.2 & 14 & 6 & 12 & 24 & $\begin{array}{l}\text { Bulging } \\
\text { deformation } \\
\text { and } \\
\text { bending } \\
\text { deformation }\end{array}$ & $\begin{array}{l}\text { Debnath } \\
\text { and Dey, } \\
2017\end{array}$ & $\begin{array}{l}I=30 \mathrm{~cm} \\
d=5 \mathrm{~cm}, \\
s=2.5 \mathrm{~d}, \\
\text { mat } \\
\text { thicknes } \\
40 \mathrm{~mm}\end{array}$ \\
\hline 6 & 10 & 8.75 & 3.68 & 14 & 3 & 12 & 24 & $\begin{array}{l}\text { Bulging } \\
\text { deformation } \\
\text { and } \\
\text { bending } \\
\text { deformation }\end{array}$ & $\begin{array}{l}\text { Debnath[ } \\
\text { Dey, } 2017\end{array}$ & $\begin{array}{l}I=30 \mathrm{~cm} \\
d=5 \mathrm{~cm}, \\
s=2.5 d, \\
\text { thicknes } \\
30 \mathrm{~mm} f \\
\text { geosynt } \\
\text { reinforci } \\
\text { sand ma }\end{array}$ \\
\hline 7 & $<5$ & 6 & 2 & & 11.34 & 30 & 22 & $\begin{array}{l}\text { Shear } \\
\text { failure at } \\
\text { pile top }\end{array}$ & $\begin{array}{l}\text { Alkhorshid, } \\
2017 ; \\
\text { Alkhorshid } \\
\text { et al, } 2019\end{array}$ & $\begin{array}{l}I=40 \mathrm{~cm} \\
d=15 \mathrm{~cm}\end{array}$ \\
\hline 8 & $<5$ & 5.35 & 2 & - & 11.95 & 16 & 16 & $\begin{array}{l}\text { Shear } \\
\text { failure at } \\
\text { pile top }\end{array}$ & $\begin{array}{l}\text { Alkhorshid, } \\
2017 ; \\
\text { Alkhorshid } \\
\text { et al, } 2019\end{array}$ & $\begin{array}{l}I=40 \mathrm{~cm} \\
d=15 \mathrm{~cm}\end{array}$ \\
\hline 9 & $<5$ & 2.67 & 2 & - & 12.53 & 8 & 15 & $\begin{array}{l}\text { Shear } \\
\text { failure at } \\
\text { pile top }\end{array}$ & $\begin{array}{l}\text { Alkhorshid, } \\
2017 ; \\
\text { Alkhorshid } \\
\text { et al, } 2019\end{array}$ & $\begin{array}{l}I=40 \mathrm{~cm} \\
d=15 \mathrm{~cm}\end{array}$ \\
\hline 10 & - & 25.4 & - & - & 6.5 & 40 & 10 & $\begin{array}{l}\text { Shear } \\
\text { failure }\end{array}$ & $\begin{array}{l}\text { Gu et al., } \\
2017\end{array}$ & $\begin{array}{l}\text { Uniaxial } \\
\text { compre؛ }\end{array}$ \\
\hline 11 & $1.25 \sim 1.36$ & 0.15 & 1.5 & 28.1 & 27.1 & 0.26 & 13 & - & $\begin{array}{l}\text { Hong et } \\
\text { al., } 2016\end{array}$ & $\begin{array}{l}l=25 \mathrm{~cm} \\
d=5 \mathrm{~cm}\end{array}$ \\
\hline 12 & $1.25 \sim 1.36$ & 0.3 & 1.5 & 28.1 & 15.8 & 0.75 & 45 & - & $\begin{array}{l}\text { Hong et } \\
\text { al., } 2016\end{array}$ & $\begin{array}{l}l=25 \mathrm{~cm} \\
d=5 \mathrm{~cm}\end{array}$ \\
\hline 13 & $1.25 \sim 1.36$ & 0.5 & 1.5 & 28.1 & 18.7 & 7.42 & 49 & - & $\begin{array}{l}\text { Hong et } \\
\text { al., } 2016\end{array}$ & $\begin{array}{l}I=25 \mathrm{~cm} \\
d=5 \mathrm{~cm}\end{array}$ \\
\hline 14 & $1.25 \sim 1.36$ & 0.025 & 1.5 & 28.1 & 29.1 & 0.05 & 25 & - & $\begin{array}{l}\text { Hong et } \\
\text { al., } 2016\end{array}$ & $\begin{array}{l}I=25 \mathrm{~cm} \\
d=5 \mathrm{~cm}\end{array}$ \\
\hline 15 & $1.25 \sim 1.36$ & 0.3 & 1.75 & 28.1 & 13.1 & 0.25 & 92 & - & $\begin{array}{l}\text { Hong et } \\
\text { al., } 2016\end{array}$ & $\begin{array}{l}I=25 \mathrm{~cm} \\
d=5 \mathrm{~cm}\end{array}$ \\
\hline 16 & 5 & - & 0.8 & - & 27 & 2.45 & - & - & $\begin{array}{l}\text { Dash and } \\
\text { Bora, } 2013\end{array}$ & $\begin{array}{l}l_{\text {esc }}=1 d, \\
\text { floating }\end{array}$ \\
\hline 17 & 5 & - & 3.5 & - & 16 & 2.45 & - & - & $\begin{array}{l}\text { Dash and } \\
\text { Bora, } 2013\end{array}$ & $\begin{array}{l}l_{\text {esc }}=3 d \\
\text { floating }\end{array}$ \\
\hline 18 & 61 & - & $\begin{array}{l}\text { 3 4 (under } \\
\text { encasement) }\end{array}$ & - & 1.16 & 100 & - & $\begin{array}{l}\text { Bulging } \\
\text { under } \\
\text { encasement }\end{array}$ & $\begin{array}{l}\text { Lee et al., } \\
2008\end{array}$ & $\begin{array}{l}\text { In-situ t } \epsilon \\
d=80 \mathrm{~cm} \\
l_{\mathrm{esc}}=3 d\end{array}$ \\
\hline
\end{tabular}

Where, / presents pile length; $d$ presents pile diameter; $l_{\text {esc }}$ presents encasement length; $s$ presents pile to pile space; and $H_{d}$ presents embankment height. 
The maximum deformation of the stone column (SC) is larger than that of the geosynthetic encased stone column (ESC) at limit load, and the former one maybe achieve 4.7 times the latter one. The deformation of the fully encased stone column is much smaller than that of the SC at limit load if the encasement strain difference at the pile failure and at the encasement failure is much large. That is to say, if the encasement still has much strength to develop after the pile fails, the deformation of the ESC is much smaller than the SC. The ESC may fail from upper punching or bending with high stiffness of encasement, at which case the ESC behaves as a rigid pile. When the encasement stiffness is low, the ESC may fail from bulging. However, the increase of the encasement stiffness induces more cost. This suggests that in ESCs composite ground design, the balance between the pile stiffness and cost should be given attention. The partially encased stone column may fail from bulging under encasement.

\section{Conclusions And Discussion}

This paper studies the static characteristics of ESCs, including bearing capacity and deformation. The main conclusions and suggestions are made, as follows,

- The bearing capacity of ESCs composite ground mainly influenced by encasement modulus, encasement length, ratio of pile length to diameter, area replacement, soil shear strength and mat thickness. The allowable bearing capacity of the ESCs composite ground is 1.5 to 8.5 times that of the SCs. The limited bearing capacity of the ESCs composite ground is 1.1 to 9.4 times that of the SCs.

- The stress concentration ratio of the ESCs composite ground is influenced by pile stiffness, shear strength of surrounding soil, area replacement ratio and length to diameter ratio. The stress concentration ratio is between 0.48 and 31 for the ESCs composite ground.

- If the encasement still has much strength to develop in the state of pile failure, the ESC behaves as rigid pile, which may fail from upper punching or bending. When the encasement stiffness is low, the ESC may fail from bulging.

\section{Declarations}

\section{Acknowledgements}

This work is supported by the Science and Technology Research Project of Education Department of Hubei Province (D20213001).

\section{References}

1. Alkhorshid NR (2017) Analysis of geosynthetic encased columns in very soft soil. Dissertation, University of Brasilia

2. Alkhorshid NR, Araujob GLS, Palmeira EM, Zornberg JG (2019) Large-scale load capacity tests on a geosynthetic encased column. Geotext Geomembr 47(5): 632-641. https://doi.org/ 10.1016/j.geotexmem.2019.103458.

3. Almeida MSS, Hosseinpour I, Riccio M, Alexiew D (2014) Behavior of Geotextile-Encased Granular Columns Supporting Test Embankment on Soft Deposit. J Geotech Geoenviron Eng 141(3): 04014116. https://doi.org/10.1061/(ASCE)GT.1943-5606.0001256.

4. Chen JF, Li LY, Zhang Z, Zhang X, Xu C, Rajesh S, Feng SZ (2021) Centrifuge modeling of geosynthetic-encased stone column-supported embankment over soft clay. Geotext Geomembr 49(1): 210-221. https://doi.org/10.1016/j.geotexmem.2020.10.021.

5. Dash SK, Bora MC (2013) Influence of geosynthetic encasement on the performance of stone columns floating in soft clay. Canadian Geotechnical Journal 50(7): 754-765. https://doi.org/ 10.1139/cgj-2012-0437.

6. Debnath P, Dey AK (2017) Bearing capacity of geogrid reinforced sand over encased stone columns in soft clay. Geotext Geomembr 45(6): 653-664. https://doi.org/10.1016/j.geotexmem.2017.08.006.

7. Demir A, Sarici T (2017) Bearing capacity of footing supported by geogrid encased stone columns on soft soil. Geomechanics and Engineering 12(3): 417-439. https://doi.org/10.12989/gae.2017.12.3.417.

8. Duan YY (2012) Mechanical and deformation performance of composite foundation with geosynthetics encased columns. Dissertation, Zhejiang University

9. Fattah MY, Zabar BS, Hassan HA (2016) Experimental analysis of embankment on ordinary and encased stone columns. Int J Geomech $16(4)$ : 04015102. https://doi.org/ 10.1061/(ASCE)GM.1943-5622.0000579.

10. Gniel J, Bouazza A (2010) Improvement of soft soils using geogrid encased stone columns. Geotext Geomembr 27: 167-175. https://doi.org/10.1016/j.geotexmem.2009.12.012.

11. Gu M, Zhao M, Zhang L, Han J (2015) Effects of geogrid encasement on lateral and vertical deformations of stone columns in model tests. Geosynth Int 23(2): 100-112. https://doi.org/ 10.1680/jgein.15.00035.

12. Gu M, Han J, Zhao M (2017) Three-dimensional discrete-element method analysis of stresses and deformations of a single geogrid-encased stone column. Int J Geomech 17(9): 04017070. https://doi.org/10.1061/(ASCE)GM.1943-5622.0000952.

13. Hong YS, Wu CS, Yu YS (2016) Model tests on geotextile-encased granular columns under 1-g and undrained conditions. Geotext Geomembr 44(1): $13-27$. https://doi.org/ 10.1016/j.geotexmem.2015.06.006.

14. Lee D, Yoo C, Park S, Jung S (2008) Field Load Tests of Geogrid Encased Stone Columns in Soft Ground. In: Proceedings of Eighteenth International Offshore and Polar Engineering Conference, Vancouver, BC, Canada, pp 521-524.

15. Li LY, Rajesh S, Chen JF (2021) Centrifuge model tests on the deformation behavior of geosynthetic-encased stone column supported embankment under undrained condition. Geotext Geomembr 49(3): 550-563. https://doi.org/10.1016/j.geotexmem.2020.11.003. 
16. Mehrannia N, Nazariafshar J, Kalantary F (2018) Experimental investigation on the bearing capacity of stone columns with granular blankets. Geotechnical and Geological Engineering 36(1): 209-222. https://doi.org/10.1007/s10706-017-0317-6.

17. Miranda M, Da Costa A (2016) Laboratory analysis of encased stone columns. Geotext Geomembr 2016, 44(3): $269-277$. https://doi.org/10.1016/j.geotexmem.2015.12.001.

18. Murugesan S, Rajagopal K (2007) Model tests on geosynthetic-encased stone columns. Geosynth Int 14(6): 346-354. https://doi.org/10.1680/gein.2007.14.6.346.

19. Murugesan S, Rajagopal K (2010) Studies on the behavior of single and group of geosynthetic encased stone columns. J Geotech Geoenviron Eng 136(1): 129-139. https://doi.org/10.1061/ (ASCE)GT.1943-5606.0000187.

20. Ou Yang F, Zhang JJ, Fu X, Han JW, Yan KM, Du L (2016b) Experimental analysis of bearing behavior of geosynthetic encased stone columns. Rock and Soil Mechanics 37(07): 1929-1936. https://doi.org/10.16285/j.rsm.2016.07.013.

21. Ou Yang F, Zhang JJ, Liao WM, Han JW, Tang YL, Bi JB (2016a) Characteristics of the stress and deformation of geosynthetic-encased stone column composite ground based on large-scale model tests. Geosynth Int 24(3): 242-254. https://doi.org/10.1680/jgein.16.00028.

22. Zhao MH, Gu MX, Zhang L, Liu M (2014) Model tests on influence of vertical geosynthetic-encasement on performance of stone columns. Chinese Journal of Geotechnical Engineering 36(9): 1587-1593. https://doi.org/10.11779/CJGE201409003.

\section{Figures}

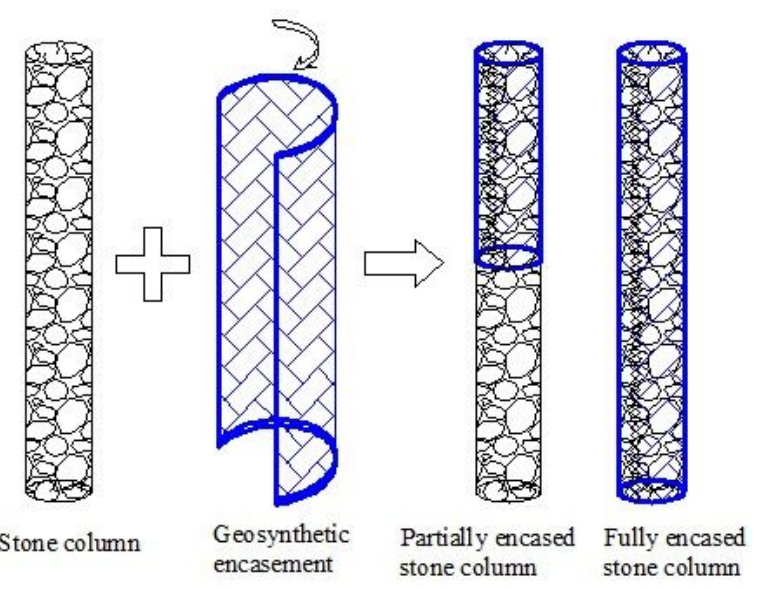

Figure 1

ESC including partially encased stone column and fully encased stone column 


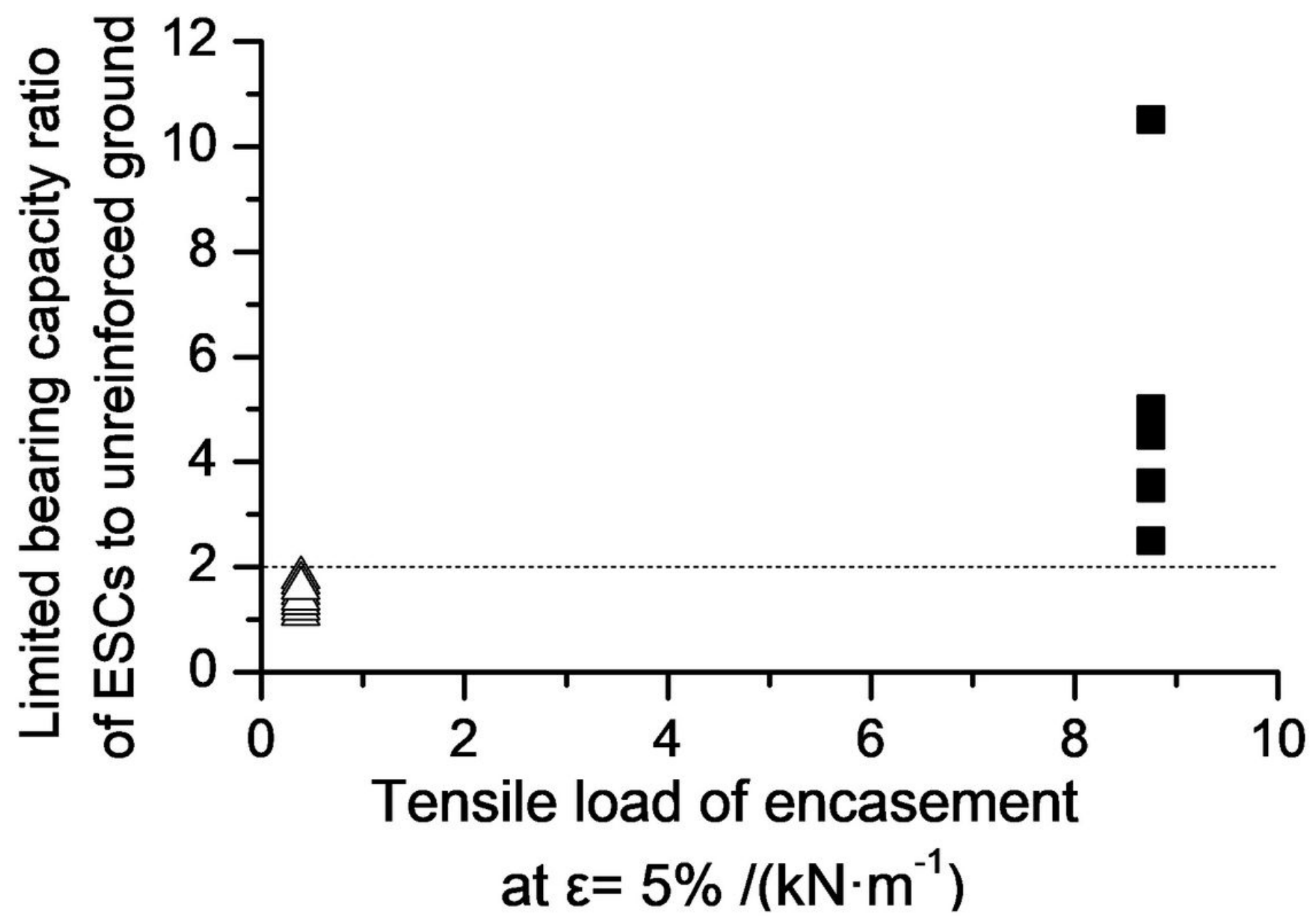

Figure 2

Limited bearing capacity ratio of ESCs to unreinforced ground (Murugesan and Rajagopal, 2010; Fattah et al., 2016) 